\title{
Latour and Literary Studies
}

\section{AM INTERESTED IN QUESTIONS OF READING AND INTERPRETATION.}

\section{AM ALSO DRAWN TO ACTOR-NETWORK THEORY AND THE WORK OF}

Bruno Latour. Can these attractions be brought into alignment? To what extent can a style of thought that describes itself as empiricist and rejects critique speak to the dominant concerns of literary studies? Can actor-network theory help us think more adequately about interpretation? Might it inspire us to become more generous readers? How do literary studies and Latourian thought engage, enlist, seduce, or speak past each other? What duels, rivalries, intrigues, appropriations, or love affairs will ensue?

While Latour acknowledges a debt to the Greimasian model of actor or actant, his explicit references to literature have been largely a matter of passing observations and lapidary remarks. Meanwhile, Latour's work ignores or explicitly rejects many of the themes that have occupied literary scholars in recent decades: representation, the linguistic turn, textuality, the symbolic, negativity, alterity. In certain respects, it seems to resist being taken up as a generalizable method at all. In the dialogue at the center of Reassembling the Social, a hapless doctoral student drops in on a Latour avatar during office hours, seeking advice about how to apply actor-network theory to his dissertation, only to encounter obstacles at every turn. Actor-network theory, it turns out, is a theory not so much about how to study things as about "how not to study them-or rather, how to let the actors have some room to express themselves" (142). How might this radical empiricism, as Latour calls it with a nod to William James, be reconciled with the theory- and text-based orientation of literary studies? In particular, how could it help us reimagine practices of reading and interpretation? The prospects, at first glance, do not look promising.

Yet this pact of mutual noninterference is reaching its end, as Latour's work receives ever more attention in literary studies. The most lively fields in literary criticism include animal studies, thing theory, ecological thought, the posthuman-all fields premised on the intertwinement and codependence of human and nonhuman
RITA FELSKI is William R. Kenan, Jr., Professor of English at the University of Virginia and editor of New Literary History. Her most recent book is The Limits of Critique ( $U$ of Chicago P, 2015), and she is starting a new book on attachment and attunement. 
actors. Given obvious affinities and shared concerns between these fields and Latour's work, it is becoming harder to avoid actornetwork theory, whether as an ally to be embraced or a rival to be denounced. Rejecting the divisions of subject/object, nature/culture, thought/matter, and language/world, Latour's work presumes the equal ontological salience of all classes of being in a mutually composed world. Hence the rhetorical force of the "Latour litany" (Bogost): the quasisurrealist lists of disparate entities-strawberries, stinkbugs, quarks, corgis, tornadoes, Tin-Tin and Captain Haddock-that convey, through their promiscuous entanglement and equinanimous copresence, the equal footing of nonhuman and human actors. Actor, in this sense, is not freighted with assumptions about intention, consciousness, or autonomy but designates any and all phenomena whose existence makes a difference.

Actors exist not in themselves but only through their networks of association. Ties, in a Latourian framework, are not limits to action but a fundamental condition for action. The relevant distinction is not between freedom and bondage but between kinds of linkage: "As to emancipation, it does not mean 'freed from bonds' but well-attached" (Reassembling 218). Actor-network theory is thus a matter of tracing out the paths by which entities of all kinds-from scallops to subway trains, from springboks to boxsprings-are constituted by their relations. Given the hybridity of networks, whatever is transmitted is also translated, transposed, and transformed. It is hardly surprising, then, that actor-network theory is sometimes described as a sociology of mediation.

Yet this leveling of phenomena through their incorporation into networks also poses a difficulty for the uptake of actor-network theory as a method in literary studies. What, then, accounts for the distinctiveness of literature? How might a Latourian style of thought connect to what most literary critics care about? How could it help us read? To be sure, actor-network theory has certain affinities to the growing field of cultural ecology as well as to cultural studies and its method of articulation. ${ }^{1}$ At first glance, however, it seems removed from the traditional concerns and methods of literary studies, including a focus on interpretation. The interaction between Latour and literary studies thus looks like one of those one-sided wrestling matches that canny promoters rigged in advance. Either themes from actor-network theory are incorporated into existing practices of close reading (the critic traces out the movement and interconnection of actants within the confines of a literary work), or actor-network theory draws us toward a sociology of networks that can be exceptionally illuminating but seems remote from the interpretative concerns of literary studies. Is it possible to come up with a less lopsided form of interaction?

Latour's most recent book speaks directly to this question. Reflecting on the influence and legacy of actor-network theory, Latour ruefully notes that the anthropologist of networks "has lost in specificity what she has gained in freedom of movement. ... As she studies segments from Law, Science, The Economy or Religion, she begins to feel that she is saying almost the same thing about all of them: namely that they are 'composed in a heterogeneous fashion of unexpected elements revealed by the investigation"' (Inquiry 35). Here Latour speaks to the problem at hand: that an overemphasis on the varying associations among multiple actors results in a flattening of persistent differences. How can we acknowledge the plurality and interconnectivity of phenomena while also honoring the salient differences between networks? How do we attend to both mixtures and contrasts? Such a reorientation would seem necessary if Latour's work is to speak well to the concerns of literary critics.

Latour develops the notion of "mode of existence" (taken from Étienne Souriau) to 
speak about what distinguishes science, law, technology, religion-and art. In contrast to cartographic metaphors such as field or domain, with their connotations of discrete and bounded spaces, mode of existence identifies differences without delineating borders. We can agree, for example, that literary texts are connected to countless things that are not literature, while also acknowledging that there cluster around literature certain ways of talking, experiencing, acting, interpreting, and evaluating. It is crucial, Latour remarks, to speak about a mode of existence in its own language: to engage its criteria of verification and value, its conditions of felicity and unfelicity. At the same time, however, his project is also one of redescription: the theories we hold about these various modes of existence often do not match up very well with our experiences and practices.

These arguments speak to my interest in the uses of literature: the forms of attachment through which texts entice and enlist us, surprise and seduce us (Felski, Uses). Such attachments testify to our lives as social beings, while inviting us to reflect on the distinctive qualities of works of art: what spurs us to pick up a book or to become engrossed in a film. I share Latour's conviction that prevailing styles of scholarly analysis often fail to capture the nature of our entanglement with texts, as a precondition for forging better accounts of why these texts matter. For example, Latour emphasizes the realness of works of art as well as that of the fictional characters that inhabit them-honoring intuitions that are often waved away as naive by professional critics. We have already noted his lack of interest in the language-world distinction; the question of whether fiction reflects or distorts a social context disappears from view. Neither, however, are we sealed off from reality by an impermeable screen of signification or textuality. Rather, the task of the critic is to follow the actors along the networks of words, things, ideas, images, and practices through which they are constituted. In this sense, poems and paintings possess as much ontological reality as nitrogen or Napoleon: they are actors knotted into forms of association that enlist our interest and help make things happen. The beings of fiction, Latour remarks, do not "direct our attention toward illusion, toward falsity, but toward what is fabricated, consistent, real" (Inquiry 238). As such phrasing suggests, for actor-network theory realness and fabrication are connected rather than opposed; that Emma Bovary was made by Gustave Flaubert and a subsequent stream of critics, translators, commentators, filmmakers, and audiences does not decrease or diminish her reality but makes it possible. ${ }^{2}$

Because agency is composite, actornetwork theory also steers us away from monocausal explanations of what and how a text signifies. Who is fabricating whom? Agency is distributed, uncertain, and hard to pin down. Against a view of meaning as determined only by readers or interpretative communities or social fields, Latour also insists on the unmistakable pressure and power of the text: "A work of art engages us, and if it is quite true that it has to be interpreted, at no point do we have the feeling that we are free to do 'whatever we want' with it. ... Someone who says 'I love Bach' . . . receives from Bach, we might almost say 'downloads' from Bach, the wherewithal to appreciate him" (Inquiry 241). Works of art invite and incite us, in ways that we do not always expect and may not be able to predict. They orient us in certain ways and draw us down interpretative or perceptual paths. They possess their own ontological dignity instead of just being screens on which we project our preexisting fantasies and ideologies. In this way, Latour provides a way of accounting for the sturdiness and liveliness of texts as nonhuman actors that move across time as well as space (Felski, "Context").

And yet works of art also need our devotion. Their existence depends on their being taken up by readers or viewers, as 
intermediaries through which they must pass, without whom they will soon be reduced to "failure, loss, or oblivion: abandoned stage sets, rolled up canvases, now useless accessories, incrusted palettes, moth-eaten tutus" (Inquiry 248). Hence the real and irresolvable ambiguities of agency: we make works of art even as they make us. What is the difference between being carried away by a narrative and by a subway train? It is not that one experience is false or illusory while the other is real, remarks Latour: rather, the former requires our solicitude and active participation in a way that the latter does not. A critical ethos of attentiveness, respect, and generosity comes to the fore, though shorn of any transcendental trappings. Aesthetic experience does not oppose or reject society (this language makes no sense in a Latourian framework) but is created out of networks of association: an artwork acquires its singularity from its social ties, not from being opposed to them.

Attachment is thus an indispensable term in the Latourian lexicon. We become attached to art objects in a literal sense: the dog-eared paperback that rides around town in a jacket pocket, the lyrics streaming through the headphones glued to a person's ears, the Matisse postcard propped up on a desk that is transported from one sublet to the next. Such texts form part of an Umwelt: a bodycentered web of relations to phenomena that bear meaning for us. Attachment, of course, also points us toward the adhesiveness of affect: being entranced by a work of fiction, dreaming in front of a painting-or falling in love with the protocols of critical theory and academic reading. Reason cannot be filtered out from the ebb and swirl of moods and dispositions: matters of fact are also matters of concern. Through diction and tone as much as argument, Latour draws us away from the prototype of the knowing, ironic, detached critic. And finally attachment is an ontological fact, an inescapable condition of existence. Critical thought often dreams of a subject without ties, of breaking free of restraints to achieve emancipation. The choice, however, is not between attachment and detachment, between determination and freedom, but between good and poor attachments, those that help us and those that seek to do us harm ("Factures" 22).

What might this mean for questions of literature and interpretation? Actor-network theory emphasizes both the necessity and the sheer difficulty of description, of attending to an empirical world that often resists or refutes our assumptions. Objectivity is not owned by the positivists, Latour remarks; that we are shaped by our situation does not prevent us from giving better or worse accounts of things at hand (Reassembling 146). This means taking care not to conjure textual meanings out of preexisting assumptions or explanationshonoring and detailing the singular features of a text as well as the specific routes along which it travels. Actor-network theory does not exclude the political-it is deeply interested in conflicts, asymmetries, strugglesbut its antipathy to reductionism means that political discourse cannot serve as a metalanguage into which everything can be translated. The task is to account for as many actors as possible, to be specific about forms of causation and connection (which are also forms of translation), instead of hitching a free ride on a preexisting theoretical vocabulary: the familiar isms waiting eagerly in the wings, all too ready to take on a starring role. ${ }^{3}$

Description, however, is not opposed to interpretation. Latour is certainly impatient with a hermeneutic philosophy that brags about the interpretative ingenuity of the human subject vis-à-vis a mute and inert world. Still, he does not reject interpretation so much as expand and extend it: "hermeneutics is not a privilege of humans, but, so to speak, a property of the world itself" (Reassembling 245). ${ }^{4}$ That is to say, countless entities are engaged in interaction, mediation, adaptation, and translation: the world is not a 
dead zone of reification but as rife with ambiguity as any modernist poem (Connor). And yet, within this expanded frame, how human beings make sense of poems or paintings retains its salience, for it offers clues to art's specific mode of existence. Interpretation, we might say, constitutes one powerful mode of attachment, whose mechanisms are not well captured by the prevailing assumptions of literary studies. Within a Latourian framework, we do not probe below the surface of a text to retrieve disavowed or repressed meanings, nor do we stand back from a text to "denaturalize" it and expose its social constructedness (Felski, "Digging Down"). The distinction between a knowing critic and an unknowing text-or a naive readercrumbles away. Reading becomes a matter of composing and cocreating, of forging links between things that were previously unconnected. (Think, for example, of the impact of the "madwoman in the attic" trope on the research agenda of early feminism, forging new and powerful networks of attachments between a cohort of female critics entering the academy and a certain corpus of nineteenthcentury texts.) To interpret something is to add one's voice to that of the text: to negotiate, appropriate, elaborate, translate, and relate. The emphasis is on acts of making rather than unmaking, composition rather than critique, substantiating rather than subverting; as Graham Harman remarks, negativity plays virtually no role in Latour's thinking. ${ }^{5}$

The emphasis on distributed agency, moreover, has implications for the frame of analysis. What counts as relevant to the meaning of a work of art? Numerous possibilities crowd into view: "the whims of princes and sponsors ... as well as the quality of a keystroke on the piano, the reactions of a public to an opening night performance, the scratches on a vinyl recording or the heartaches of a diva" (Latour, Inquiry 243). Instead of a wall separating the inside of a text from its outside, we are faced with a crowd of squabbling, jostling, interconnected actors playing their parts. If we take the lessons of actor-network theory to heart, we are thus less inclined to pore over a single text to draw out its hidden plenitude of aesthetic, philosophical, or sociopolitical truth-to buy into the ethical charisma of the literary critic as privileged messenger (Love). Yet actor-network theory also pulls out the rug from under the sociologist's dispassionate analysis of a literary system: from such a bird's-eye view, everything looks remarkably similar, things blur together, and essential details are lost. Neither close reading, then, nor distant reading but what we can call mid-level reading: ${ }^{6}$ an approach not grounded in the revelatory value of a single work or in a general notion of society or literary system but positioned on a scale between the two. Interpretation? Yes, without a doubt-but of objects and mediations as well as literary works, a practice of lateral reading across multiple texts rather than deep and intensive reading of a single text (Outka). On the one hand, a more capacious view of what counts as relevant to literary analysis; on the other hand, an insistence that a text cannot be manhandled into the role of a mirror, index, or symptom of a social whole.

The alliance of actor-network theory and literary studies, like all alliances, requires translation, tinkering, and diplomacy. Rather than apply Latour to literary studies in one-sided fashion, we do better to elucidate overlapping interests and common concerns. And here, I have argued, questions of reading and interpretation are not inimical to actornetwork theory, even if they take on differing guises. Instead of engaging in a hermeneutics of suspicion, we conceive of interpretation as a form of mutual making or composing. Instead of stressing our analytic detachment, we own up to our attachments, shrugging off the tired dichotomy of vigilant critic versus naive reader. Instead of demystifying aesthetic absorption, we see that experience as a key to the distinctive ways in which art solicits our 
attention. In this scenario, in short, literary studies is neither safeguarded nor subverted; it is reoriented and recomposed.

\section{NOTES}

1. See, e.g., Kelleter's illuminating account of The Wire as a text coauthored by a network of agencies.

2. On the reality of fiction, see also Warner's helpful discussion.

3. For good accounts of the political dimensions of Latour's work, see Piekut; Harman, Bruno Latour.

4. In recent essays and interviews, Latour points to the influence of his doctoral training in biblical exegesis on his subsequent thinking (e.g., "Coming Out" 601).

5. As Harman puts it with his usual verve, "The very idea of a Latourian treatise on negativity makes me burst into laughter" ("Importance" 34).

6. I coin this phrase by analogy with Frow's discussion of mid-level concepts in the sociology of literature.

7. Muecke offers an interesting example of such recomposition. I am thankful to Stephen Muecke, Benjamin Piekut, and Bill Warner for their helpful comments.

\section{Works Cited}

Bogost, Ian. Alien Phenomenology; or, What It's Like to Be a Thing. Minneapolis: $\mathrm{U}$ of Minnesota P, 2012. Print.

Connor, Steven. "Spelling Things Out.” New Literary History 45.2 (2014): 183-97. Print.

Felski, Rita. “Context Stinks!” New Literary History 42.4 (2011): 573-91. Print.
"Digging Down and Standing Back." English Language Notes 51.2 (2013): 7-24. Print.

- Uses of Literature. Oxford: Blackwell, 2008. Print.

Frow, John. “On Mid-Level Concepts.” New Literary History 41.2 (2010): 237-52. Print.

Harman, Graham. Bruno Latour: Reassembling the Political. London: Pluto, 2014. Print.

. "The Importance of Bruno Latour for Philosophy." Cultural Studies Review 13.1 (2007): 31-49. Print.

Kelleter, Frank. Serial Agencies: The Wire and Its Readers. Winchester: Zero, 2013. Print.

Latour, Bruno. "Coming Out as a Philosopher." Social Studies of Science 40.4 (2010): 599-608. Print.

. "Factures/Fractures: From the Concept of Network to the Concept of Attachment." Res: Anthropology and Aesthetics 36 (1999): 20-31. Print.

- An Inquiry into Modes of Existence. Cambridge: Harvard UP, 2014. Print.

- Reassembling the Social: An Introduction to ActorNetwork-Theory. Oxford: Oxford UP, 2005. Print.

Love, Heather. "Close but Not Deep: Literary Ethics and the Descriptive Turn." New Literary History 41.2 (2010): 371-92. Print.

Muecke, Stephen. "Motorcycles, Snails, Retour: Criticism without Judgement." Cultural Studies Review 18.1 (2012): 40-58. Print.

Outka, Elizabeth. "Dead Men, Walking: Actors, Networks, and Actualized Metaphors in Mrs. Dalloway and Raymond." Novel 46.2 (2013): 253-74. Print.

Piekut, Benjamin. "Actor-Networks in Music History: Clarifications and Critiques." Twentieth-Century $\mathrm{Mu}$ sic 11 (2014): 1-25. Print.

Warner, William B. "Reality and the Novel: Latour and the Uses of Fiction." Latour and the Eighteenth Century. Ed. Christina Lupton and Sean Silver. Spec. issue of Eighteenth Century: Theory and Interpretation 57.2 (forthcoming 2016). 